\title{
Challenges and Solution of Nigerian Non-Interest Islamic Banking
}

\author{
Nasiru Saidu \\ ${ }^{1}$ Department of Business Administration, Bauchi State University Gadau, Nigeria \\ Correspondence: Department of Business Administration, Bauchi State University Gadau, Nigeria. Email: \\ Nasirinta@ gmail.com. Tel: +234 8035905206
}

Received: January 20, 2018

Accepted: January 23, 2018

Online Published: January 29, 2018

\begin{abstract}
The Nigerian non-interest Islamic banking engenders varieties of debate, simply because the system is build based on Islamic principles. Islamic banking is market determinants with the moral principles and teaching of Islamic shariah, also an arrangement of saving money so as to steady by means of the standards of Islamic rule (Shari'ah) as well as practices through the improvement of Islamic economies. The paper examines idea, the challenges and prospects of non-interest banking in Nigerian dealing with some banks managers, employees, Muslims and non Muslims citizens, and library research by evaluation and examining various findings on the subject under study. Due to the high population and progressive opportunity, the study shows that nigeria has an opportunity of being a leader of African Islamic finance, but there are some various obstacles, challenges to the development of Nigerian Islamic finance which an instance Religious and cultural differences, inadequate of Financial Innovations, Lack of adequate knowledge, high Competition and Shari'ah Related Issues and so on. The paper therefore recommends that Nigerian religious bodies and Central Bank of Nigeria ought to continuously organizing seminars, training and lectures on Islamic finance to banks staff, tertiary institution student, academicians as well as general public on adequate explanations of the aims also objectives as well as advantages of Islamic banking, also the institution should be highly be creative and innovative, attracting and maintaining well trained qualified employees.
\end{abstract}

Keywords: Islamic banking; Shariah complaints, Challenges, prospects, Nigeria.

\section{Introduction}

Islam is not merely means among the greatest monotheistic religion, suggestive of total submission to the will of Allah and also a "deen", means 'the way of life'. It touches upon the material as well as religious dimensions of individual survival. It doesn't limit itself to a profound relationship amongst man and Allah or portrays the Almighty just with a supernatural reference additionally controls, in right extents, an intelligent relationship amongst man and man, and amongst man and society with good, political and monetary beginning. Subsequently, it is a religion lived in consistently life and no Muslim is in any uncertainty as how to do his daily activities throughout his life.

Islamic banking refers to non-interest banking or interest free banking it is progressively developing into international financial system. The contemporary Islamic banking has originated from Egyptian experiment of alternative saving institution that used musharakha profit allotment in the city of mit Ghamar in 1963, and also be lance managed by economist Ahmad El-Naggar. Consequently, the Nasir social bank in Egypt is affirmed as Islamic banking in 1971, even though their license is not in position with Islamic or compliant of Islamic shariah (Ariff 1988). The fundamentals standards of shariah bank and Islamic investment are to offer end to end monetary services guided by shariah complaints. The primary source of shariah is Islamic law reveled in the glorious Quran and authentic tradition (Sunnah) of prophet Muhammad (SAW).

The banking system is extremely important for every country economic growth and development. The accepted 
view of every commercial conventional banking is based on predicated on intermediation and make their net profit in the course of their two main operations which includes receiving cash deposits from their customers in which the banks pay them interest after, which is called bank liability and giving out personal and corporate loans in which the banks received interest from them as their income. This explains into the source of determining the margin of interest flanked by borrowing and savings rates. This explains that conservative banking arrangement is built on interest in which their activities and development is based on interest pays and charge. Therefore the expansion of banking opens a new boundary for conventional banks to develop their activities ahead of their traditional business to source their income through non interest income. Going by the name non-interest revenue is incomes that do not begin or has to do with interest on any transactions. The expansion of Islamic bank revenue advanced the sector productivity and decreases the danger of the borrowing procedure by more diversification of banking action (Hakimi, Hamdi \& DJelassi, 2012)”.

Despite all the role significant plays by non interest Islamic banking towards the country economic growth and development especially developing country like nigeria, majority of nigerians are not supporting the banking activities an instance nigeria have over 25 commercial banks but now only one bank, Jaiz Bank Plc that fully operates non interest Islamic banking also this bank is besieged with operational challenges which be inclined to hold back its competitiveness with conventional banks in the country. More over these challenges includes religious and cultural differences, low customers patronizing, lack of adequate knowledge, Inadequate of Financial Innovations loan defaulter, disloyalty of trust, fallacy of Islamic economic curriculum, bank policies and regulations moral hazard, lack of qualified manpower high Competition and Shari'ah related issues as well as double taxation issue this challenges create major seat bank to the nigerian non interest Islamic banking.

\section{Problem Statement}

Due to the high population and progressive opportunity, the study shows that Nigeria has an opportunity of being a leader of African Islamic finance, but there are some various obstacles to the development of Nigerian Islamic banking. Among the challenges facing Nigerian Islamic banking are insufficient manpower, be short of Shari'ah - acquiescent liquidity management instrument, no standard (Takaful), Islamic insurance, short of understanding of accounting and auditing as a standard required by Islamic bank operations, lack of standard advisory committee, problems of multiple taxation, high rivalry from conventional banks, lack of full support by the country administration Misperception by others religions thinking of Islamic banking is belongs to only Nigerian Muslims (Sanusi LS 2011). Most negative effects associated with Nigerian Islamic finance come from divergent beliefs, norms and culture that lead to major challenges in the system. Thus, the objective of this paper is to appraise the Islamic banking challenges with a view to finding out whether or not its principles can be applied as a solution to the problem.

\section{Conceptual Framework}

Theoretical structure segment gives an clarification of non interest Islamic banking by making distinction from Islamic banking gap, it provides clear explanation to the idea of Riba (interest), essential philosophy of Islamic banking, method of activities, and good reasons for non-interest bank window within nigeria.

\section{Research Methodology}

The methodology used in the preparation of this paper is to study the library with the document content analysis method. Additional information is obtained from various documents and references to the official website of the relevant agencies. The study also uses content analysis method to data obtained from the literature scholar, newspaper and website in question. The information obtained is used to view the Challenges and prospects of Nigerian Non-interest Islamic banking.

After basic examination of the devastating effects of the challenges, the author considered proffering answer for 
the problem as a result of which some observation were made with some companies' managers, employees and environmentalists. The author utilizes these as a part of expansion desk research to build up the paper. Effort was made to concoct workable recommendations that can spare the unsafe circumstance.

\section{Definition of Islamic Banking}

Meanings of non-interest bank spun approximately one thing - Islamic rule (Shari'ah). This is able to comprehend in the taking after descriptions as of various writers. In support of example, Sanusi (2011) analyzed non-interest bank, another option that structure financial intermediation in which focus on profit making. Meaning that Islamic banking is market determinants however with the moral principles and teaching with Islamic shariah Akram et al. (2011) views non interest bank arrangement is an arrangement that found on Islamic principles, rules and shariah that direct the organization. Besides, Lawal (2010) characterized non-interest banking system as an arrangement of saving money so as to steady by means of the standards of Islamic rule (Shari'ah) as well as practices through the improvement of Islamic economies. Also, Marimuthu et al. (2010) characterize the lead of transaction system in light of Shari'ah standards. In a similar line, Ghayad (2008) perceive non-interest banking system as a framework that works as per the tenets of Shari'ah i.e. Fiqh al-Muamalat (Islamic guidelines on exchanges). Taking everything into account, Islamic banking is a sort of managing an account framework that works entirely premise of Islamic rule.

Now a day's banks produce an expanded extent of their income from non-interest transactions and activities. As instance US commercial banking business generate over forty percent of their operating income through non-interest banking transactions (DeYoung and Rice, 2004). In fact non-interest banking system has developed into principal elements of generating incomes by commercial bank globally. Moreover due to non-interest system of commercial banks the interest income as a principal indicator of conventional banking revenue has reduced radically and non interest returns augmented significantly.

Therefore interest free revenue is predicated on the support in creating banking (bank and borrower) revenue first and foremost from fees. For instance of non-interest revenue comprises deposit transaction charges, inadequate money fees, check book and ATM card fees, monthly account maintainace charges, and account reactivation charges. Based on interest free banking managing an account structures, foundations charge expenses that gives non-interest a way of creating income and guaranteeing liquidity in case of expanded non-payment rates.

\section{The Concept of Riba (Interest)}

Riba is refers to interest or usury and have been explain by diverse writers in various views, several of this authors are in same views, but several attempt to make it distinction as of interest received in traditional conservative banking arrangement with loosing discuss. What is Riba? Riba factually stand for 'excess' or 'increase' on top of the principal amount of the credit (Abraham, 2008). Abraham set off ahead to state that Riba implies usury because is an innately ill-conceived rehearses which has been denounced inside Qur'an. More over Seed (1996) in Lawal (2010) explain Riba as any quantity on top of initial principal of the loan gives out to the asset owner due to the additional of due date for his defaulter with postponement of reimbursement obligation. Consequently Riba is alienated keen on two, Riba al-Fadl and Riba al-Nasiah. Riba al-Fadl and Riba al-Nasiah. Riba al-Fadl is the kind of Riba that is related with superiority in direct swap over of commodity. It implies the excellence best in return of low superiority by way of improved superiority products. The idea of Riba al-Fadl alludes to deal exchanges. Whereas Riba al-Nasiah implies an augmentation on vital of a credit or obligation owed. It likewise alludes with act of loaning cash for a period of time on the considerate which client would come back to the bank toward the finish of the period the sum initially loaned collectively with an expansion on it, in light of the moneylender have allowed him an opportunity to pay regardless of misfortune or benefit. 
Interest (Riba) is forbidden by all main religions, Islam, Christianity and Judaism all this they have condemned receiving or giving money on money "interest" and the entire its consequence. The glorious Qur'an openly also categorically rejects receiving or pay out interest on any transaction whether commercial or civil. Qur'an, clearly express in Surah Al-Imran (3:130), Allah declares: "O you who believe! Do not consume Riba (usury) increase it over and remain your responsibility to Allah that you may flourish". Glorious Qur'an clearly express the same type of this prohibition regarding (Riba) fixed interest in many verses and instance affirmed in Al-Baqarah (2:275-281), -Nisa (4:160-161) also in Surah Al-Rum (30:39) of the Qur'an. There are many authentic tradition of Prophet Muhammad (SWA) which clearly expresses the prohibition of (Riba) interest and anything that is uncertainty (Gharar). Both of this two interests and uncertainty is not allowed in Islam shariah. More over there is absolute agreement between all four school of thought the word "Riba" stand for interest in all types and forms (Ariff, 1988).

On the other hand Christians Bible express that taking of interest is firmly prohibited. Exodus (22:25) says: "If you loan cash to any of my kin who are poor between you, you might not resemble a cash money lender to him; you should not charge him premium." Leviticus (25:35-37) states: "In the event that one of your brethren gets to be distinctly meager, and falls into neediness in the middle of you, then you should assist him, similar to an outsider or a sojourner that he is living with you. Take no interest or enthusiasm from him; however obey God that your sibling that he is living with you. You might not loan him your cash for interest, nor loan him your food at a benefit."

Same thing with the authoritative manual for Hebrew likewise institutionalize enthusiasm paying or receiving as in Deuteronomy (23:19) says: "Thou shalt not loan upon enthusiasm to thy sibling; usury of cash, usury of foodstuff, usury of everything that is loaned upon usury." The usury is utilized as a part of a similar vein of any extra sum attest by lender above or over the genuine sum higher the by him shoulder to account holder.

\section{Basic Features of Islamic Bank}

Non interest banking is exceptional types of banking arrangement which prohibits all types of dealings that has to do with Riba, Uncertainty, and producing or consuming illicit products. Therefore all banks with certificate of Islamic bank window they should to adopt the followings basic principles in their operation (Greuning et al 2008):

a) Avoidance of interest (Riba) It is generally prohibited in Islam to have set prearranged sum in adding up to actual amount it is totally condemned in Islam. Therefore any bank engage in Islamic transaction they most to isolate their selves in any forms of interest and focus on profit sharing and loss bearing.

b) Prohibition of Uncertainty (gharar). The word gharar means uncertainty and literally means hazard. Therefore any transaction that have high probability of uncertainty or too much hazardous and are connected with gambling is prohibited. Because Islam forbids conjecture, a potential Islamic therefore Islamic bank keeps away from all dealings with extreme risk.

c) Profit, loss, and risk sharing. In view of the fact that interest is forbidden in Islam, therefore Islam open a door for profit and loss sharing in banking settings. In Islamic arrangement the supplier of the funds and the entrepreneur they have to share the profit and loss based on agreed ratio, through doing this will help to insure equality of income distribution, poverty reduction and improved social justice.

d) Shari'ah accepted dealings. Non-interest system is an arrangement that is build stand on Islamic rules that is shariah. Therefore any transaction that is against or prohibited by Islamic shariah is not allowed in Islamic. For instance wine, alcohol, clubs financing, gambling, haram food financing etc. all are forbidden. Islamic banking system can only involves in transaction or activities that are approved by shariah advisory committee.

e) Justice. Islamic forbids all Muslims to engage their selves in any transactions that are unfairness to others or 
exploiting any party in any form. Therefore Islamic banking cannot engage in any transaction has to do with injustice or mistreatment of someone.

f) Obligatory payment of zakat. It is compulsory for Islamic banking to pay zakat as at when due. Zakat is among the five fillers of Islam therefore Islamic banks most to take zakat into account.

g) Supervise by Shari'ah advisors. Islamic banks, ought to guided and regulated by the Islamic law experts that will have review on their every activities Islamic banks and their services to ensure that they abide by principles of shariah.

\section{Principles of Islamic Banking}

Method or procedure of operations in interest free bank is various also has a space for further advancement in their methods of their activities gave they are in accordance with muamalat standards. Underneath anyway, confine to principals:

a) Qard Hasan loans: It is a considerate credit agreed to a well deserved customer by interest free banks to reduce paucity. Also recipient is necessary by Shari'ah to give just only principle to the Islamic bank. Notwithstanding, the customer may pay an expansion to prove gratefulness to the interest free bank however this goal ought not be unveiled to bank by the client toward the commencement of business.

b) Mudaraba: A Mudaraba Agreement is a money related exchange whereby two parties in the agreement. One party will give the required resources (Rabb-ul-Maal) while the other party will do dealing as business person (Mudarib). Means interest free bank be as resources contributor (Rabb-ul-Maal). In this sort of budgetary agreement, benefits are shared among bank and the business person (customer) in light of predetermined proportion. In any case, in case of misfortune the bank (or contributors) tolerate the misfortune also the business person mislay his or her exertion gave it was not thus of his or her carelessness. Mudaraba agreement is of two sections in Islamic keeping money framework. One a player in the agreement is flanked by the Islamic bank and contributors, while other party is between the bank and the business person.

c) Murabaha: This kind of agreement is for the most part employing in obtainment of equipments. It is a trade agreement involving non-interest bank and its customer at a repaired benefit name mark-up. In this agreement, the customer will give every one of the details specification of the item and the Islamic bank will go out on a limb of buying it for the customer at a cost in addition to increase which the customer can pay instalmentally or whole at a time or at an expressed time.

d) Ijarah (Lease): Ijarah is identical to renting agreement in traditional conventional banking. It is an agreement that Islamic bank purchased an assets as well as rents it away to its customer on the understanding that the customer will paying a specific amount on regular intervals it can be usually monthly, quarterly or annually for a predefined timeframe to the Islamic bank. It might likewise incorporate the alternative of the customer buying the advantage toward the finish of the agreement from the bank.

e) Musharaqa (Equity Partnership): Musharaqa is an agreement that at least two people contribute resources for the organizing of specific business enterprise in a manner that each accomplice has appropriate to include in the organization of the business or not. Therefore a partner has a right to choose to participate or dormant partner in the business. Moreover in this kind of business in Islamic the profit used to share among the partners based on agreed ration which need to be same with the amount contributed. Along these lines, Islamic bank will go about as an accomplice for this situation to give the resources arrangement also sharing revenue and loss.

g) Salam (Forward Trade Contract): Salam means feature delivery contract, is an agreement by which interest free bank agrees to bring a commodity to the customer (its customer) at specific agreed date by the two parties that explain in swap of an advanced full spot disbursement to the bank. Meaning the customer pays the complete sum but the deliverance of the product will be in the specific date open agreed by the parties. 


\section{Islamic Bank in Nigeria}

The 1999 constitution of federal republic of Nigeria proved the right to freedom to practice your religion which cuts across all individual activities. Based on Islamic rules muslims are not allowed for a muslims to engaging themselves in any transaction that has to do with interest, gambling or gharar this necessitates the to the establishment of non interest Islamic banking system to enable nigerian muslims to practice their constitutional rights which is not opportunity, due to this fact nigerian Islamic banking is justified with a full constitutional backing (Abikan, 2009). Furthermore Nigerian non interest Islamic banking provides an opportunity to their customers to choose their investment option. As malami (2009) express that non interest Islamic banking gives their customers the alternative of investment with respect to time deposit account. This opportunity cannot be offer by conventional banking system.

Furthermore central bank of Nigeria has launched new adaptable framework for non interest Islamic banking simply because it cannot separate the system from the global transformation in the financial system recommended by Islamic financial system. In addition there is high demand for the system due to the large numbers of Muslims in northern and south-western parts of the country who are prepared to benefit from non interest Islamic banking services.

Moreover central bank of Nigeria CBN explanation expresses that, non-interest banking is required to act in accordance with the philosophy of shariah jurisprudence. The base of Islamic finance is prohibition of interest, meaning that all transaction in Islamic finance is interest free and risk sharing among the parties. The forbidden of interest is based on the influence with social impartiality and fairness (Shafique et al, 2012; Fatai, 2012; Wilson 2009; Lodhi and Kalim, 2005). Also the forbidden of riba is been clearly express in many chapters of the Holy Quran, including chapters 2:275; 2:281 3:130; 4:161; and 30:39.

Even though Islam prohibit predetermined or guaranteed of profit on capital, also plat rate of profit on factors of production, but it allowed sharing profit among the transaction parties. Therefore the ration to share profit is free arrange is prearrange, but the return ratio cannot be predetermined. Non-interest Islamic banking is there to tailor the needs of those who understand the prohibition of interest and its consequences in the society. Consequently the Islamic banks carried out their activities related to conventional banks but in compliant with Islamic laws and principles also commercial Jurisprudence (or Fiqh al-Muamalat) or Shari'ah.

\section{Literature Review}

A various research on problems of non-interest Islamic banking have been carried out in various country globally for the propose of organizing Islamic banking and it is procedures. More so some of this research are conducted in a single country understanding (Jabr, 2003; Saleh et al,) whereas others are carried out in various country globally system (Iqbal et al, 1998; Ariss et al,). One nation research is based on a specific country understanding whereas the multi countries system is findings based on the universal method of Islamic finance.

Based on this part we will evaluate the precise findings of Akram et al. (2011) which used explanatory investigation to understand the expansion and improvement as well as prediction of Pakistan Islamic banking structure. Based on his findings there is marvelous expansion in participation and transacting of Islamic banking finances, which shows the increase and expansion of non-interest banking in Pakistan. Moreover he explains that the prospects of non interest banking are based on the fact that Pakistan is an Islamic dominated country. The researcher the non-interest banking will continues improving each and every year, as a result of growing interest in conservative banks in non-interest banking behavior and presentation in Pakistan, and the development in performance of non-interest banking. Moreover Akram et al. squabble that the main problems of Pakistan Islamic banking rivalry and differences in norms and values.

The researches by Amin (2008) on internet business in Islamic point of view its forecast and problems in 
Malaysian financial system. Amin proposed that the Malaysian prospect internet business is mainly based on their administrations support, mode of Islamic finance principles relax in development of man power, economics of scale and developing the internet facilities to benefit users. More so the obstacles comporting Islamic internet is lack of good support from the consumers, Islamic internet business charges, a required of good multifaceted infrastructure as well as lawful risks issues.

A findings of Jabr (2003) bring to a close that the main obstacles and prospects of non-interest banking activities in Palestine includes the followings: failure of standard banking regulations for Islamic banking system, be short of knowledge, survival of infertile funds, lack of equipped segregation between non-interest and conventional banks, short of solid knowledge of Islamic shariah, lack of adequate financial instruments, lack of modern equipments and technology to support the banking system, in adequate financial modernism, failure to used of Mudaraba and Musharaqa and other Islamic mode of finance, lack of well trained and knowledgeable staff that can support the system and incapacity to distinguished from management and the ownership of capital.

Njanike (2010) which used explanatory investigation to understand the obstacles, problems as well as challenges that the Islamic banking faces at introduction. The findings of his study reveals that the major obstacles as well as challenges of initiating Islamic banking in Zimbabwe political interference in the assortment of funds borrowers, monetary unsteadiness, lack of government to reinstate regulation and regulate in the nation, lack of modern technology for transactions and organization communication, irregularity in decision making and execution of the economic and monetary authorities, the unqualified staff by the central bank to supervised and control Islamic banking sector, failure of Islamic banks inter transaction, misunderstanding the non-interest banking, mixing conventional and Islamic bank money in the same bolt, and non-payment culture

Saleh et al. (2005) implement ratio examination to inspect the Lebanese understanding with non-interest Islamic banking because the underpinning of the first Islamic bank. Based on his findings is, insufficient knowledge by the staff, failure to engage in heavy research and development, problems with community awareness and recognition, high rivalry from conventional banks, lack of full support by the country administration, these are the main problems of non-interest banking in Lebanon. On the other hand there is hopeful that Lebanon Islamic banking will flourish due to the fact that they have capacity of attracting different investors $n$ the country, due to the fact that Islamic banking plays a crucial role in economic developments which includes, agriculture, small scale business, increasing telecommunications, industries sectors and have a long run policy of increasing their customer and support the country in general as well as private ownership.

Lastly, Sanusi (2011) investigate the major problems and challenges confronting Nigerian Islamic banking. Based on his findings the principal problems is Nigerian Islamic banking are insufficient manpower, be short of Shari'ah - acquiescent liquidity management instrument, no standard (Takaful), Islamic insurance, short of understanding of accounting and auditing as a standard required by Islamic bank operations, lack of standard advisory committee, problems of multiple taxation, high rivalry from conventional banks, lack of full support by the country administration Misperception by others religions thinking of Islamic banking is belongs to only Nigerian Muslims

Based on this section is evaluation of universal findings of Islamic banking. Ahmad et al. (2010) he proposed that the responsibility of Takaful and its fame in the worldwide insurance division. All are of the opinion that they have insufficient capable and qualified employees in both conservative insurance and Shari'ah finance, be short of modern technology for transactions and organization communication, low awareness of the system application of International Financial Reporting Standard (IFRS) as a substitute of AAOIFI standard in countries where Takaful is new, lack of innovations and development, insufficient explanation and knowledge of what makes Takaful, be short of capable and well trained employees with required skills and expertise, and the 
inequality in the move toward of accounting activities and Shari'ah law are the obstacles of Takaful.

Ariss et al. (2007) examines risk administration also assets sufficiency principles in interest free banking. The findings reveals that the projected principles of support one the base two agreement ignore the origin of resources of a conservative banks also evaluate risk actions alone happen from the usage of such resources. This will express you the projected principles are partiality to Islamic banking scheme. The research additionally express that extra problems non-interest banking are liquidity risk, be short of wide coverage of imitative instrument, also complication in quantity shariah acquiescent.

A study of Dusuki and Aboizaid (2007) the obstacles in understand the maqaeid al-Shari'ah in modern monetary transactions. They also express that the main obstacles are lack of insufficient sympathetic of maqaeid al-Shari'ah and a variety of instruments in Islamic law, lack of sufficient knowledge of the main objective of shariah also it is relevant to modern business transaction and lastly circumventing the forbidden of Riba.

Iqbal (2001) Express that the main obstacles confronting non-interest financial institutions are the short term financial instruments are inadequate also long term and medium terms are also limited, non-interest finance coverage is also narrow, attentiveness of Islamic banking, risk administration and supremacy framework also poor. The researcher suggest the sufficient risk administration diversifying organization, stipulation of non-banking financial activities, also expansion of capital markets that are islamically compliments to increase the procedures and process, and help to achieved the competitive advantages positively.

A research of Shaukat et al. (2011) are in view of the deficient of good governance that will regulate the non interest financial industry, lack of experience and well equipped personnel in both non-interest and conventional banking, short of standard shariah advisory committee, lack of short-term asset investment all those are constitutes the obstacles drawing non-interest banking back. Moreover he also states that non-interest banks are very low in innovation and developments, low standard services, transparency and answerability is very minimal, etc this are the obstacles facing non-interest banking.

In fact both studies of non-interest banking from specific and general findings, we can comprehends that the influence of well trained and experienced personnel in both conventional and Islamic banks, innovations and developments in financial activities, well equipped shariah advisory commission, sufficient legal structure, modern equipments, standard services and lots more. Can be takes into account for institutional improvements.

\section{Challenges and Recommendation}

In the process of the research, the Challenges and solution of Nigerian Non-interest Islamic banking, the following are the problems arrived:

\section{Religious and Cultural Differences}

One of the main problems of Nigerian non interest banking is religion and cultural barriers in the country. Nigerian is a country mixed with different beliefs norms and culture. This religious and cultural issue is a serious issue that needs efficient solution for Nigerian non interest banking to continue moving forward. This is because others beliefs that are not Muslims have the perception that if they participate in Islamic banking like they become muslins or they are helping Islamic religions, this misperception cause major seatback of non-interest banking in nigeria.

\section{Inadequate Human Resources}

The continued existence of Nigerian Islamic banking is extremely defends on sufficiently well equipped and experienced personnel, in training, research, teaching in Islamic mode of finance and also with wealth of knowledge of both conventional and Islamic finance also economics. Research and development, teaching, merely a handful of universities based to have various programmed concerning Islamic mode of finance, teaching and carry out massive studies on both Islamic and conservative banking. The findings of their research 
are both personnel and capital improvements with the need to improve the institutional survival in Nigeria. The rational of teaching research is to developed well equipped personnel because having indigenous personal will be cost effective compare to haring of personnel from outsides the country.

Inadequate of Financial Innovations

Due to technological improvements the customer's needs always increase, and the financial markets is changing rapidly, therefore there is need for Islamic banks to design their financial services as well as their products that will tailored their customers' requirements, needs or their test. More so there is lack of monetary modernization for Nigerians Islamic institutions, also setback in executing new products or services due to principles or guidelines laid by Islamic shariah. Due to these makes non-interest banking flexible to innovations.

Lack of adequate knowledge

Insufficient knowledge of non-interest baking will obstruct its expansion in Nigeria. Due to low understanding of Islamic banking principles, activities, services as well as their products to the general community influence the system development in the country. Therefore the investors and the consumers of non interest banking are very anxious about the achievements of Nigerian non-interest banking. Most of other people are having mistaken believe or perception towards Islamic banking, which comprises non-interest banking is not advantageous since it cannot charge or pays interest, non-interest banking is only takes place in Muslims dominated areas, Islamic banking is provided by Muslims only.

\section{Double taxation issue}

The Nigerian tax decree needs some alteration to think of interest free banks services into the account, or else there is serious threat due to multiple taxation which would be charge on non-interest banks due to assets accumulation tax, stamp duty tax and various tax from state governments that are charges on their funds transfers. Non-interest banking faced a marvelous problems based this in which their financial activities is based on assets. Competition

Non-interest banking is an organization that has surprisingly developed and growth globally. But non-interest banking is now having heavily rivalry in financial markets in nigeria and some conventional banks are currently change to full fledge of non-interest transactions and some open are offerings non-interest banking windows. These banks are more progress in fully activities of financial dealings that will amplify rivalry confronting non-interest banking.

\section{Shari'ah Related Issues}

This is because non-interest banking is based on religious aspects, any financial or transactions improvements in the system must tally with shariah complaints. Therefore due to the fact that any new innovations on their products cannot be implement unless there is improvement from shariah advisory commission board also is not contradicted to Islamic laws. Therefore this is a major challenge that delays Islamic banks of being easily innovating in their financial activities simply because they must to west a time waiting for approval from shariah advisory committee.

\section{Poor Supervisory Framework}

Nigerian Islamic banking is having too much challenge on unproductive administrative structure from Shariah advisory commission as well as central bank of the country. This is happened as the fact that the two main bodies are contradicting subject matter instead of harmonizing together and also shortage of experts in both shariah advisory commission as well as central bank of the country itself.

\section{Recommendation}

- Based on the first finding the misperception problems of non-interest banking by other religion can be tackling by the help of central bank of Nigeria, Nigerian religious bodies engaged on massive seminar about 
the institutions, by creating awareness, knowledge on benefit of non-interest banks to the society, adequate explanations of the aims also objectives as well as advantages of Islamic banking. All this is essential for Nigerian Islamic banking to survive achieved its objectives also competitive advantages.

- The second issue Inadequate Human Resources, moving forward for Nigerian non-interest banks with respect to human resources challenges is to sufficiently finance their higher learning with adequate funds to conduct teaching and research on both conventional and non-interest banking, also set up additional institutions providing different programmed in the subject matter. More over the Central Bank of Nigeria ought to continuously organizing seminars, training and lectures on Islamic finance to banks staff, tertiary institution student, academicians as well as general public.

- Based on the third challenge Inadequate of Financial Innovations, for nigerians Islamic banking to achieved immediate developed markets atmosphere and achieved competitive advantages directly, they most to be highly creative and innovative which will help them to tailor their customers need and wants, through providing efficient and effective services to their clients.

- The recommendation for fourth problem, because of the following miss perception towards Islamic banking therefore massive seminars, programs showing benefits of non-interest banking to Muslims and non-Muslims and knowledge on Islamic banking to citizenry that Islamic banks is belong to everyone also is an alternative finance that delivers optimal satisfaction to everyone. The responsibility of making the concept to be understood by the general public is a burden the on approved providers of Islamic banking services and the monetary supervisory body (an instance CBN and SEC) have a vital responsibility to play in developing non-interest banking in Nigeria. But this can only be achieved through timely programmes, lectures, seminars and some campaign through media for crating better knowledge to the general public on Islamic banking system.

- The solution for double tax on non-interest banking Nigerian tax decrees needs to consider non-interest banks to modify their tax regulations in order to favor Islamic banks from multiple taxations. This is previously did in some countries an instance UK and Luxembourg have already modify their tax regulations which protect Islamic banks from multiple taxation on their assets for financing activities (Fatai, 2012).

- Based on competition, therefore non-interest can only endure in Nigerian financial market by innovating their services, attracting and maintaining well trained qualified employees and increasing efficiency and effectiveness in their performance.

- Shari'ah Related Issues, based on this challenge Islamic bank should try to come up with varieties of products as well different monetary instruments for them to have shariah advisory committee approval, which will help them to cope with the delay in adopting and implementation of new products in the future.

- In order to cope with Poor Supervisory Framework challenges, central bank of nigeria and shariah commission are in the position to prearranged and suffiently monitor and control all the Islamic banking activities also look after public concern towards nigerians with capable and competent personnel in the areas.

\section{Conclusion}

In order to evaluate the challenges faced by Nigerians non-interest banking, the research is arranges into various segments, which start from the introduction, theoretical structure of Islamic banking, review of various findings on challenges faced by Islamic banking in different countries including nigeria and finally express the challenges and recommendations for Nigerian Islamic banking. The research discusses the potentials of non-interest banking in Nigeria with respect to the large market in the country and has a legitimate support in respect to customer's investment choice. The recent Nigerian central bank regulatory structure in respect to non-interest 
banking is very beneficial compare to conventional banking among the benefit includes: no interest, no uncertainty, equalization in income distribution, legal transactions, free to participate on any lawful transaction and no profit guaranteed on capital. Despite all this benefits of non-interest banking but still facing lots of challenges in nigeria, an instance most of others nigerians religions are thinking Islamic banking is belong to only nigerians muslims, lack of qualified and experience staff, double taxation, high competitions, shariah related issues, lack of innovations as well as Poor Supervisory Framework. Based on the recommendations by the author those problems can be solve by Nigerian religious bodies, massive seminar by the institutions, by creating awareness, knowledge on benefit of non-interest banks to the society, More over the Central Bank of Nigeria ought to continuously organizing seminars, training and lectures on Islamic finance to banks staff, tertiary institution student, academicians as well as general public.

\section{References}

Abikan, A. I. (2009). "Constitutionality of Islamic Banking in Nigeria". In: Justice Tdris Legbo Kutigi (eds) Contemporary Issues in Islamic Jurisprudence. Benin: Rawel Fortune Resources.

Abraham, I. (2008). "Riba and Recognition: Religion Finance and Multiculturalism" Essays from the AASR Conference.

Ahmad, M. I, Masood, T. \& Khan, M. S. (2010). "Problems and Prospects of Islamic Banking : a case Study of Takaful”. MPRA Paper No. 22232, Posted 20 April, 2010 / 16:55.

Akram, M., Rafique, M. \& Alam, H. M. (2011). "Prospects of Islamic Banking: Reflection from Pakistan". Australian Journal of Business and Management Research, 1(2).

Amin, H. (2008). "E - Business from Islamic Perspectives: Prospects and Challenges". Journal of Internet Banking and Commerce, 13(3).

Ariff, M. (1988), “Islamic Banking”, Asian-Pacific Economic Literature, 2(2) (September), 46-62.

Ariss, R. T. \& Sarieddine, Y. (2007). "Challenges in implementing capital adequacy guidelines to Islamic banks". Journal of Banking Regulation, 9(1).

DeYoung, R., and T. Rice (2004), "Non-interest income and financial performance at U.S. commercial banks", The Financial Review 39,101-127.

Dusuki, A. W. \& Aboizaid, A. (2007). "A Critical Appraisal on the Challenges of Realising MAQAeID AL SHARI'AH in Islamic Banking and Finance". IIUM Journal of Economics and Management, 15(2).

Fatai, B.O. (2012), “Can Islamic Banking Work In Nigeria?”, Journal of Sustainable Development in Africa, $14(2)$.

Ghayad, R. (2008). "Corporate governance and the global performance of Islamic bank" Journal of Humanomics, 24(3).

Greuning, H. V. \& Iqbal, Z (2008). "Risk Analysis for Islamic Banks". The International Bank for Reconstruction and Development/World Bank.

Hakimi, A., H. Hamdi and M. DJelassi (2012), "Modeling Non-Interest Income at Tunisian Banks", _Asian Economic and Financial Review 2(1), 88-99.

Iqbal M., Ahmad, A. \& Khan, T. (1998). “Challenges Facing Islamic Banking”. Islamic Development Bank, and Islamic Research and Training Institute Occasional Paper No. 1.

Iqbal, Z (2001). "Challenges Facing Islamic Financial Industry”. Journal of Islamic Economics, Banking and Finance.

Islamic Financial Stability Forum, (2010). "Islamic Finance and Global Financial Stability" Task Force Report of Islamic.

Jabr, H. (2003). "Islamic Banking in Palestine Challenges and Prospects". An - Najah Univ. J. Res. (H.Sc), 
$17(1)$.

Lodhi, S. A., Kalim, R., \& Iqbal, M. (2005). Strategic Directions for developing an Islamic

Banking System [with comments]. The Pakistan Development Review, 1003-1020.

Malami, H. U. (2009). "Towards Developing Islamic Techniques of Economic Development" Sokoto, Nigeria: Department of Economics, Faculty of Social Sciences, Usmanu Danfodio University.

Marimuthu, M., Jing, C. W., Mum, L. P. \& Ping, T. Y (2010). "Islamic Banking: $\quad$ Selection $\quad$ Criteria $\quad$ and Implication”. Global Journal of Human Social Science, 10(4).

Njamike, K. (2010). "Introduction of Islamic Banking in Zimbabwe: Problems and Challenges". Journal of Sustainable Development in Africa, 12(8).

Saleh, A. S \& Zeitum, R (2005). "The Development of Islamic Banking in Lebanon: Prospects and Future Challenges". Review of Islamic Economics, 9(2).

Sanusi, L. S. (2011)."'Islamic Finance in Nigeria: Issues and Challenges" Lecture Delivered at Markfield Isntitute of Higher Education (MIHE), Leicester, UK, 17 June, 2011.

Shafique, A., Faheem, M. A., \& Abdullah, I. (2012). Impact of global financial crises on the islamic banking system: analysis of islamic financial system during financial crunch 2008. Arabian Journal of Business and Management Review (OMAN Chapter), 1(9), 124.

Wilson, R. (2009). Why Islamic Banking Is Successful? Islamic Banks Are Unscathed Despite of Financial Crisis. Islam Online. net.

\section{Copyrights}

Copyright for this article is retained by the author(s), with first publication rights granted to the journal.

This is an open-access article distributed under the terms and conditions of the Creative Commons Attribution license (http://creativecommons.org/licenses/by/4.0/). 